\title{
Impact of Pesticides use on Honeybee Mortality, Honey Yields and Quality in Transmara West Sub- County, Kenya
}

Gabriel Dida ( $\sim$ gdidah@gmail.com )

Technical University of Kenya

Paul Aboum

Maseno University

Kanda Richard

Maseno University

Douglas Anyona

Maseno University

Tomislav Mestrovic

University of North Croatia

Magenya Oscar

Kenya Agricultural and Livestock Research Organization

\section{Research Article}

Keywords: Apiary, Colony, Forage, Pesticide, Residue, Sanitation, Season, Senescence

Posted Date: February 8th, 2021

DOl: https://doi.org/10.21203/rs.3.rs-157753/v1

License: (9) (i) This work is licensed under a Creative Commons Attribution 4.0 International License. Read Full License 


\section{Abstract}

Background: The honeybee (Apis mellifera L.) is an important insect that produces honey wax and royal jelly, and propolis that thought to fight infections. It also acts as a cross pollinator of both agricultural and wild plants. However, honeybee colonies are presently faced with a number of constraints both globally and locally. Like in many parts of the world, hive colonization and honey yields in Transmara West Sub-County of Kenya have been on a decline; attributed partly to increased pesticide use. This study thus set out to establish the impacts of pesticides use on honeybee mortality rate and honey production by screening honeybee, honey and pollen for pesticide residues.

Methods: A longitudinal descriptive survey and experimental design was adopted for the study. Sixteen apiaries were selected and two strong colonies in Langstroth hives identified in each apiary. These were replicated once to bring the total to 64 colonies, which acted as controls and treatments. Traps were fixed at hive entrances to aid in collection of dead bees at weekly intervals for a period of six months (March to October 2015). Samples of honeybee colony matrices among them pollen loads, honeybee and honey were collected from the identified colonies and analyzed for amitraz, chlorfenvinphos, cypermethrin, deltamethrin and malathion residues using Queshers method at Maseno University chemistry laboratories.Differences in honeybee mortality rate and honey yields between experimental sets were established by one way ANOVA followed by a Turkey HSD post hoc test. A structured questionnaire was also administered to select bee keepers to evaluate their perception on and role in pesticide use. Their responses were analyzed using the $\chi^{2}$ test or Fisher's exact test.

Results: Mortality rate in treated colonies $(229 \pm 5.1)$ was significantly higher than in control colonies $(73 \pm 11) ; M S D=4.6791, p=0.01$. Likewise, honey yield in control colonies $(16.0 \pm 1.0 \mathrm{~kg})$ was significantly higher than in treated colonies $(8.7 \pm 1.2 \mathrm{~kg}) ;(M S D=4.8425, \mathrm{p}=0.024)$. For instance, the average season one honey yield in the control colonies was $18.0 \pm 1.0 \mathrm{~kg}$ compared to $7.1 \pm 1.10 \mathrm{~kg}, 8.4 \pm 1.50$ and 9.2 $\pm 1.7 \mathrm{~kg}$, in treated colonies. This implies that increased pesticide use may have contributed to increased honeybee mortality rate and reduced honey yields. No residues were detected in all honeybee colony matrices, implying that honeybee products within the study settings were safe for consumption. Majority of farmers reported observing changes in honeybee colony strength, a reduction in honey yields, reduced colony size, significantly weakening the colonies.

Conclusion: This study established an inverse relationship between pesticides use honeybee mortality rate, with significant increase in mortality rate and reduced honey production being associated with its use. Absence of residues in the matrices in all the studied sites suggests honeybee products from the study setting are still safe for human consumption. Nevertheless, farmers need to be trained on safe handling of pesticides. In addition, there is need for further research on the synergistic impacts of pesticides use on honeybees, and the need for alternative and ecofriendly pest control options to curb the challenge associated with indiscriminate effects of pesticides on other important insects like honeybees. 
Globally honeybee populations have shown a declining trend with North America and European beekeepers reporting about $30 \%$ loss in their honeybee colony populations in the past 30 years $[1,2]$. In the Sub-saharan Africa, the dwindling numbers of Apis mellifera L. can be attributed to some extent to lack of skills and knowledge on honeybee keeping among beekeepers and also to numerous environmental factors [3]. However, since no study has strongly linked a single factor to colony losses [3], scientists, policy makers and beekeepers altogether, concur that several factors may act synergistically to curtail the survival of honeybee colonies; key ones being climate [4] and indiscriminate use of pesticides [5]. Honeybees often come into contact with a number of pesticides while foraging for pollen and nectar as well as through contaminated water [6]. Nevertheless, pesticides have been shown to trigger changes in the biological functioning and behavior of honeybees resulting in their memory loss, which impairs homing ability, dysfunction of the immune system, as well as uncoordinated foraging activities [7-9]. In France for instance, the queen bee's daily laying capability was reported to have declined when worker bees brought back contaminated materials, including pesticides into the hives [10]. Studies have also shown that up to $32 \%$ of honeybees that are exposed to pesticides often fail to return to their colonies, while those that return and are laced with contaminated pollen have the capacity to infect the entire colony resulting in honeybee colony decline. Beekeepers near flower farms and tea estates in Uganda and Kenya reported a decline in bee colonies, which they attributed to pesticide toxicity [11].

Though pesticide usage is known to affect honeybees even at sub-lethal doses, there is dearth of information on the impact of pesticides use on the honeybee and the subsequent impact on honeybee colonies and honey yields. Studies indicate that honey production in Kenya has been declining $[12,13]$ and the decline has anecdotally been attributed to parasites, pathogens, and pesticide use [14]. Other factors like modification of their natural habitats have also been cited as contributing to honeybee colony decline [15-17], making it necessary to establish the relationship between honeybee mortality rates, honey yield and quality of the honey.

Despite widespread use of pesticides in Transmara West Sub-County, there is scarcity of information on pesticide residues in different honeybee colony matrices like honey, pollen and nectar to effectively inform honeybee management policy. Moreover, the effect of pesticide on honeybee is unknown despite its' potentially detrimental risk not only to the honeybee but also to human health; with many beekeepers singling out pesticides as the most likely cause of the decline in honeybee colony population in most bee keeping areas. Lack of such critical information may impede optimal honey production and therefore impact negatively on the beekeeping venture, necessitating this study.

\section{Materials And Methods}

\section{Study site}

Transmara West Sub-county covers about $2900 \mathrm{~km}^{2}$ and consists of four administrative units (Lolgorian, Angata, Kilgoris and Keiyan) [Figure 1]. The sub-county lies between latitudes $0050 \mathrm{~S}$ and $1050 \mathrm{~N}$ and

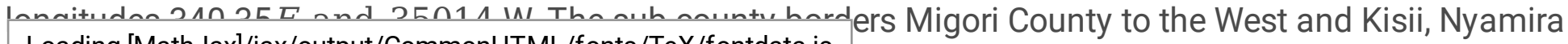
Loading [MathJax]/jax/output/CommonHTML/fonts/TeX/fontdata.js 
and Bomet Counties to the North. Rainfall is bimodal with mean temperature ranging between $14.8-20.3$ ${ }^{\circ} \mathrm{C}$. Livestock production and crop farming are the key economic activities for most households in the region.

Other notable activities include sand harvesting, and tourism.

\section{Study Design}

This study adopted a longitudinal descriptive and experimental study designs. Sixteen apiaries apiaries were selected from which two strong colonies in Langstroth hives were identified in each apiary and replicated once totaling to 64 colonies that acted as control and treatments. Selection of strong colonies in each apiary was through observation of comb area covered by adult bees, capped and open brood, honey yields and pollen, presence of eggs, and visual sighting and status of the queen. The colonies were further checked for diseases and parasites incidence. In addition, a household survey on pesticide use patterns was conducted among residents drawn from Angata, Logorian and Kilgoris Divisions of Transmara West Sub-County. The sampled households were selected using a random numbers table and pesticides use data obtained from them using a structured questionnaire.

\section{Experimental treatments}

, Three treatments and control were set up (Slide 1) at the Kenya Agricultural and Livestock Research Organization (KALRO) Transmara Sub-Centre. Four plots (two with maize and two with beans) of 0.125 acres each were established and two strong colonies transferred from the main station apiary and placed 20 meters from the maize and beans crop fields just after planting. Crop pests were managed throughout the crop's physiological stages including flowering stage by applying Magic (Malathion) and Keshet (Deltamethrin) pesticides following the manufacturer's instructions. Another two sets of two strong colonies managed in Langstroth hives were transferred from the main station apiary and placed 20 meters to a cattle spray crush at the KALRO Transmara Sub-Centre. Cattle at the centre were routinely sprayed with a number of pesticides among them Sypertix (alphacypermethrin), Almatix (amitraz) and Steladone (chlorfenvinphos) to control external parasites. At the main Station apiary located at a fenced and undisturbed area with natural vegetation, two apiaries were selected from which two strong colonies managed in Langstroth hives were identified in each apiary to serve as control experiment. The fence was to curtail the entry of pesticides into the colonies in the apiary through either drift or transmission by livestock. Sixteen on-farm apiaries- five each in Kilgoris and Angata and six in Lolgorian, were randomly selected and two strong colonies managed in Langstroth hives identified from each apiary. The colonies were constantly inspected for hygienic conditions and monitored for any honeybee mortalities, honey yields. Dead bee traps were fixed at each hive entrances and mortality data collected weekly for two consecutive seasons between March and July 2015. Honeybee colony matrices including honey, pollen and honeybees were collected from the hives containing the identified colonies and screened for pesticides residues using Queshers method (AOAC QuEChERS Method 2007.01) at Maseno University laboratories. The experiments were replicated once in the on-farm, treatments and control colonies.

Loading [MathJax]/jax/output/CommonHTML/fonts/TeX/fontdata.js one at the end of each season. 


\section{Monitoring honeybee Mortality rate and honey yields}

Each study hive was equipped with an under basket trap for collecting dead bees. The traps were attached to the hives at least seven days prior to the start of experiment to allow the honeybees to familiarize with the traps. The dead bee traps remained fitted until the experiment was completed. A data collection sheet designed for recording honey yields every harvest season in all the colonies identified in the selected apiaries was used to capture the data. Rates of honeybee mortality were recorded weekly during both 2015 seasons: (season 1: April-July) and (season 2: August-November), while honey production was evaluated once for each season (22-26 June 2015) and (2-6 November 2015).

\section{Collection of honeybee, honey and pollen samples}

The hives were checked weekly and the number of dead bees counted, recorded and removed. In hives whose dead bees exceeded the 250 threshold (informed by the literature) [33], in an apiary, the dead bees were sorted and samples taken to the laboratory for pesticides residue analysis. Eight dead bee samples were taken and packed in a plastic jar, put in a cool box and stored at $4{ }^{\circ} \mathrm{C}$ for subsequent pesticides residues analysis. Fifty (50) grams of freshly harvested honey from the hives containing the two strong colonies identified in all the sixteen selected apiaries were collected and packed in plastic jars and put in a cool box at $4{ }^{\circ} \mathrm{C}$, in a dark place, and later analyzed for pesticides residues. Pollen samples were collected from comb cells of the two hives containing the strong colonies identified in all the sixteen apiaries and 20 grams from each colony packed in plastic jar, put in a cool box at $4{ }^{\circ} \mathrm{C}$, stored in a dark place until their analysis. All the samples were analyzed at the Maseno University's School of Graduate Studies (SGS) laboratories for quantitative determination of pesticides residues.

\section{Pesticide residue analysis}

Pesticide residues were determined using liquid chromatography-tandem mass spectrometry (LC/MSMS) QuEChERS method [34-36]. Honeybee, honey and pollen Matrices were preserved, extracted and analyzed following the modified QueCHers analytical method (AOAC Official Method 2007.01) that uses a single-step buffered acetonitrile ( $\mathrm{MeCN}$ ) extraction and salting out liquid-liquid partitioning from the water in the sample with $\mathrm{MgSO}_{4}$. Cleanup using the dispersive-solid-phase extraction (dispersive-SPE) was carried out to remove organic acids, excess water and other components with a combination of primary secondary amine (PSA) sorbent and $\mathrm{MgSO}_{4}$. The extracts were separated using chromatographic analytical separation and analyzed by mass spectrometry (MS) technique.

\section{Equipment}

The UPLC / MS-MS (Waters. Micromass Quattro Premier XE Mass Spectrometer) was used to quantify Amitraz while GC- MS (Agilent 7890A GC -5975C Inert MSD with Multi-mode Inlet) was used for other GC- 


\section{Reagents and consumables}

The reagents and consumables used in the analysis included: Acetonitrile (Merck 1000302500- gradient grade for liquid chromatography or equivalent), Methanol (Merck 1000106035- hypergrade for LC-MS), Water (Merck 1000115333- For chromatography LiChrosolv), PSA Clean up Tube (Sigma 55282-U), $\mathrm{MgSO}_{4}$ Extraction Tube (Sigma 55234-U) obtained from Karlsruhe, Germany. Pesticide Pure standards (>99\% certified purity) were also obtained from Dr. Ehrenstrofer laboratory (Augsberg, Germany).

\section{Pesticides residue analysis in honeybee}

One gram (1g) of honeybee heads were ground and mixed with $5 \mathrm{~mL}$ of $1 \%$ acetic acid (HOAc) in MeCN and $0.5 \mathrm{~g}$ anhydrous $\mathrm{MgSO} / \mathrm{NaOAc}(4 / 1, \mathrm{w} / \mathrm{w})$. The mixture was added to a centrifuge tube bottle, shaken and centrifuged. An upper layer of the MeCN extract was added to anhydrous MgSO4/PSA sorbent (3/1, w/w; $200 \mathrm{mg}$ per $1 \mathrm{~mL}$ extract), mixed and centrifuged. The final extract was transferred to autosampler vials for analysis by gas chromatography/mass spectrometry (GC/MS) and liquid chromatography/tandem mass spectrometry (LC/MS/MS). This was done to identify and determine pesticide residues in honeybees.

\section{Pesticides residue analysis in honey}

For pesticide residue analysis in honey, two grams of honey were mixed with $5 \mathrm{~mL}$ of $1 \%$ acetic acid $(\mathrm{HOAc})$ in $\mathrm{MeCN}$ and $0.5 \mathrm{~g}$ anhydrous $\mathrm{MgSO}_{4} / \mathrm{NaOAc}(4 / 1, \mathrm{w} / \mathrm{w})$ and added to a centrifuge tube. The mixture was shaken and centrifuged. A portion of the $\mathrm{MeCN}$ extract (upper layer) was added to anhydrous $\mathrm{MgSO}_{4} / \mathrm{PSA}$ sorbent (3/1, w/w; $200 \mathrm{mg}$ per $1 \mathrm{~mL}$ extract), mixed, and centrifuged. This final extract was transferred to autosampler vials for analysis by gas chromatography/mass spectrometry (GC/MS) and liquid chromatography/tandem mass spectrometry (LC/MS/MS) for identification and determination of pesticide residues in honey.

\section{Pesticides residue analysis in pollen}

For pesticide residue analysis in pollen, one gram of pollen was mixed with $2 \mathrm{~mL}$ of $1 \%$ acetic acid ( $\mathrm{HOAc}$ ) in $\mathrm{MeCN}$ and $0.5 \mathrm{~g}$ anhydrous $\mathrm{MgSO} 4 / \mathrm{NaOAc}(4 / 1, \mathrm{w} / \mathrm{w})$ and added to a centrifuge tube, shaken and centrifuged. A portion of the MeCN extract (upper layer) was added to anhydrous MgSO4/PSA sorbent (3/1, w/w; $200 \mathrm{mg}$ per $1 \mathrm{~mL}$ extract), mixed, and centrifuged. The final extract was transferred to autosampler vials for analysis by gas chromatography/mass spectrometry (GC/MS) and liquid chromatography/tandem mass spectrometry (LC/MS/MS) for identification and determination of pesticide residues in pollen.

\section{Data analysis and presentation}


The data that was generated was captured in Microsoft Excel (Microsoft Corporation, Washington, USA) spreadsheet and analyzed using SPSS statistical software version 16 (SPSS Inc., Chicago, III., USA). Mean residue levels among matrices in the treatments, control and on-farm as well as mean residue levels between seasons were compared using a One-way analysis of variance (ANOVA). The Chi square test or Fisher's exact test was used to analyze population characteristics with the statistical significance set at $p<0.05$ (two-sided).

\section{Results}

\section{Effect of pesticides use on honeybee mortality rate}

Findings on honeybee mortality rates in the four (4) sites within Transmara West Sub-County over the two seasons are presented in Table 1. Seasonal average honeybee mortality rates were $77 \pm 5.9$ and $73 \pm$ 12.0 bees in the on-farm and control colonies, respectively. However, no significant differences $(p=0.089)$ were observed in rates of honeybee mortality between the control and on-farm colonies in both seasons.

Mortality rates between control and treated colonies were however significantly different $(p=0.01)$ between seasons. (Figure 2). For instance, mean honeybee mortality rate in the control colonies was 64.0 \pm 10 in the first season compared to $229.00 \pm 6.2,231.00 \pm 5.1$, and $235 \pm 4.3$ bees in treated colonies. Season two mortality rates exhibited similarity with that of season one whereby honeybee mortality rate in the control colonies was significantly different $(p=0.01)$ from that of the treated colonies. Precisely, mortality rate recorded in the control colonies was $82 \pm 13$ bees, compared to $228 \pm 3.5,230 \pm 4.2$ and $232 \pm 3.8$ bees in the treated colonies. Overall, mortality rates were significantly higher in treated colonies compared to control and on-farm colonies in both seasons (Season1: MSD $=5.9655$; on-farm $=68.0 \pm$ 6.1 ; control $=64.0 \pm 10$; treated $=232 \pm 5.1$; Season 2 : $M S D=3.3919 ;$ on-farm was $=85 \pm 5.3$; control $=82$ \pm 1.3 , treated $=230 \pm 5.1)[p=<0.001]$. Nevertheless, the mortality rates in the treated, control and on-farm colonies were below the maximum threshold ( 250 dead bees per station per week) to warrant further laboratory investigations.

\section{Effect of pesticides use on honey yields}

Significant differences $(p=0.027)$ were observed in honey yields between control colonies (av. $18.0 \pm$ $1.00 \mathrm{~kg}$ ) and on-farm colonies (av. $12.20 \pm 1.80 \mathrm{~kg}$ ) in season one. Similarly, there was significant differences $(p=0.019)$ in honey yields obtained from control colonies $(22.50 \pm 1.50 \mathrm{~kg})$ and on-farm colonies $(16.23 \pm 2.05 \mathrm{~kg})$ in season two. Overall, honey yields in treated colonies were significantly $(p=$ 0.024 ) lower than in the control colonies (Table 2, Figure 3). Precisely, the average season one honey yield in the control colonies was $18.0 \pm 1.0 \mathrm{~kg}$ compared to $7.1 \pm 1.10 \mathrm{~kg}, 8.4 \pm 1.50$ and $9.2 \pm 1.7 \mathrm{~kg}$ in the treated colonies. Likewise, season two average honey yields in the control colonies was $22.5 \pm 1.5 \mathrm{~kg}$ compared to $11.0 \pm 1.2 \mathrm{~kg}, 15 \pm 1.4 \mathrm{~kg}$ and $13 \pm 1.3 \mathrm{~kg}$ in treated colonies.

\section{Pesticides residues in honeybee, honey and pollen}


Samples of honeybee, honey and pollen loads were screened for five pesticides; Amitraz, Chlorfenvinphos, Malathion, Cypermethrin and Deltamethrin owing to their popularity among farmers in the study setting (Table 3). The pesticide detection limits were found to be $0.005 \mathrm{ppm}$ for chlorfenvinphos and cypermethrin while amitraz, metathion and deltamethrin had a detection limit of $0.01 \mathrm{ppm}$. The recoveries of spiked samples ranged from $87 \%$ to $94 \%$ that were above the acceptable range $>70 \%$. However, no pesticides residues were detected in all the samples.

\section{Survey results on pesticide use patterns among farmers in Transmara West Sub-County}

A total of 330 farmers comprising of $60 \%$ male and $40 \%$ females participated in the household survey Most respondents were aged between 18 and 50 years and above across the study area (Table 4).

Up to twenty (20) different pesticides were reportedly used in the study area to combat crop and livestock pests. Pyrethroids accounted for $50.1 \%$, while organophosphorous and formamidine accounted for 28.2 $\%$ and $21.2 \%$ of the total pesticides used in the study area, respectively $\left(X^{2}=14.062, P=0.0009\right)$. The number of farmers using individual products indicated that Amitraz and Cypermethrin were the most frequently used pesticides accounting for $21.2 \%$ and $33.6 \%$, respectively, of all pesticides (Table 5). Except for Cybadip, all other pesticides used in the study area were duly registered in Kenya. Most farmers preferred pyrethroids to other pesticides partly due to their broad-spectrum capability, accessibility and efficacy.

\section{Pesticide usage and honeybee colony status by in Transmara West Sub-County}

Most respondents (31.4\%) indicated that ticks were the external livestock parasite of greatest economic importance to them, while $26.2 \%$ were of the opinion that tsetse flies were a big threat to their livestock. Other livestock parasites mentioned include; ticks, mites and tsetse flies (16.4\%), tsetse flies and worms (14.4\%) and ticks and fleas (13\%). Up to $40 \%$ of the respondents singled out stem borer as a major maize pest of economic importance while $24.2 \%$ of the respondents reported aphids as causing the greatest economic losses. Bean flies infestation accounted for $12.1 \%$ of the responses, while nematodes were reported by $9 \%$ of the respondents. Over $43 \%$ of the respondents stated that their colonies were initially big, strong and high honey yielders, while $25 \%$ reported having weak colonies. About $40 \%$ recorded low honey yielding colonies, while most farmers reported observing changes in their colony strength. Up to $50 \%$ of the respondents observed a reduction in honey yields, $41 \%$ noted reduced colony size and $15 \%$ observed weakening colonies (Table 6).

The farmers acknowledged the negative effects of pesticides on honeybees with varying degrees of severity (Figure 4). About $32.3 \%$ of the respondents cited Dominex as being the most responsible for honeybee colony decline, while $40.3 \%$ believed that Sypertix was the most severe. About $15 \%$ of the respondents believed that Alfapor caused colony decline, while $13.4 \%$ and $12.1 \%$ attributed honeybee demise to Alphacymba and Cybadip, respectively. 
Lack of awareness and safety insensitivity among farmers on the honeybees' activity seems to inform their livestock spraying schedule with pesticides that is in direct conflict with honeybees breeding.

Majority of farmers had no specific schedule for pesticide spraying regardless of recommendation from the manufactures. Most farmers in Angata (78.3\%), Kilgoris (82.7\%) and Lolgorian applied pesticides weekly $(p=0.002661)$, while $20 \%, 15 \%$ and $22 \%$ of the same population preferred biweekly ( $p$-value $=$ $0.3521)$. Only $2 \%$ each of famers from the three areas applied pesticide monthly. Majority of the farmers applies pesticides in the morning hours (92.7\%) with $65.8 \%$ applying pesticides cocktails for efficacy purposes. No residues were detected in all matrices implying that honeybee products were safe for consumption. The major information sources among farmers on pesticides use were mainly obtained from neighboring farmers $(51.5 \%)$ while others obtained the information from friends $(16.2 \%)$, agrodealers $(12.3 \%)$, media $(10.2 \%)$ and extension officers $(10.0 \%)\left(\chi^{2}=62.975, p=<0.01\right)$. On reliability of information source among farmers, agriculture extension staff, leading farmers and media were most trusted at $39.4 \%, 37.3 \%$, and $23.3 \%$, respectively $\left(\chi^{2} .=4.3412, p=0.1141\right)$.

\section{Discussion}

The present study presents timely insights on the level of pesticide residues in various honeybee colony matrices. The study identified the probable sources of pesticide contamination key among them animal husbandry and agricultural activities by farmers in the area. Higher honey yields recorded in the control colonies compared to the treated colonies could have been as a result of a higher mortality rate in treated colonies that significantly reduced the number of foraging workers resulting in decreased honey yields. Studies show that exposure of colonies to pesticides - as was the case for the treated colonies in the present study - tend to weaken the colonies making it difficult for the worker bees to forage effectively with the results being a reduction in honey yields $[5,19]$. In the present study, the average seasonal honey yield was $14 \mathrm{~kg} /$ colony compared to $18 \mathrm{~kg} /$ colony reported in the past [15]. This trend is consistent with other findings that reported a decline in honey production in the Sub-County and by extension Kenya [20, 21]. For instance, the average annual honey production showed a steep decline from $20.28 \mathrm{~kg} /$ colony in 2005 to $15 \mathrm{~kg} /$ colony in 2006 further to $9.3 \mathrm{~kg} /$ colony in $2007[13,14]$. Whereas beekeeping is ideal and of highest potential in dry areas where crop farming is not viable [16], it has been characterized by low honey yields in most parts of the country [15]. A number of researchers made similar observations, though they attributed the low yields to a number of constraints, among them lack of credit facilities and lack of information on bee keeping [22]. Carroll [15], attributed the low productivity to increased agrochemicals use, deforestation, drought and theft; with pesticides being singled out as the greatest threat to the enterprise. Mutungi et al. [16] attributed competition between beekeeping and other agricultural activities; deforestation, destruction of bee forage by caterpillars, and increased pesticide use resulting in toxicity which affect bees thus hindering honey production to its potential in Kibwezi Sub-county. In Uganda, Kajobe et al. [11] noted that multi-sectoral policy contradictions and conflicts such as the use of agricultural chemicals, within the Ministry of Agriculture, Livestock, Industry and Fisheries affect honey production. It was thus evident from the present study that pesticides use result in decline in honey yields. 
The significantly higher mortality rates observed in treated colonies compared to control and on-farm colonies in the present study may be partly attributed to high pesticides exposure among treated colonies compared to control and on-farm colonies. This is because honeybees from treated colonies are likely to constantly forage in areas saturated with pesticides. Likewise, the on-farm colonies have a higher chance of exposure to pesticides that are often used by farmers to manage pests unlike the control colonies. These findings are consistent with those of $[9,23]$ who noted that colonies living near treated crops where most of their workers were exposed to pesticides in nectar throughout the cropping seasons experienced a decline in population from which the colonies would struggle to recover. The finding that the mortality rates in the treated, control and on-farm colonies were below the maximum threshold of 250 dead bees per station per week in the present study cannot however be used to rule out honeybees' deaths due to pesticide toxicity. This is because the impacts of pesticides on honeybees manifest with differing degrees of severity depending on various factors among them toxicity levels, application time, application intensity as well as physiological maturity of flowers visited by bees [24].

Further, the present findings concur with those reported by PAN [7] in which it was concluded that honeybees near agricultural fields are exposed to a variety of pesticides and at varying levels of concentrations throughout the foraging period. Whereas exposure of honeybees to high pesticides levels results in outright death of bees, sub-lethal doses result in behavioral changes like loss of navigation and communication ability, which subsequently leads to homing failure [25]. Bees that die instantly following exposure to high pesticide doses are often not captured by the trap while bees exposed to sub-lethal doses are likely to wander aimlessly due to loss of navigation ability. As a result, such bees are not likely to make it back to the hive making the mortality rate count to be significantly underestimated following the loss of foragers in the field [24]. Studies show that low pesticide concentration that are normally considered safe for honeybees have in recent times been reported to influence honeybee foraging behavior [26]. For instance, honeybees exposed to pesticides levels that were 70 times below the mortality causing levels in standard tests $\left(\mathrm{LD}_{50}\right)$ exhibited abnormal behavior like inability to return to the hive [27]. Likewise, deltamethrin doses of as low as $2.5 \mathrm{ng} / \mathrm{bee}$ (deltamethrin $L_{50}=67 \mathrm{ng} / \mathrm{bee}$ ) resulted in the disorientation of foraging bees [28]. Therefore, despite mortality rate counts being within natural limits in the present study, it would be incorrect to conclude that pesticides use did not cause a substantial reduction in colony numbers within the study setting.

Although its generally agreeable that increased pesticide use leads to a decline in honeybee populations, the mortality rates were lower in the present study compared to those reported elsewhere. In North America and Europe for instance, honeybee colony population showed a decline in the last 30 years with beekeepers reporting losses of up to $30 \%$ of their managed colonies every winter in the last seven years [2]. Moreover, up to $32 \%$ of honeybees exposed to sub-lethal pesticide concentrations failed to return to their hives in a study conducted in France, effectively doubling the natural loss rate of foraging workers [9]. This could be attributed to large pesticide quantities used and application rates in Europe and USA [29]. The acute, chronic and synergistic impact of multiple pesticide exposure greatly contribute to declinina honevbee health consequently increasing mortality rate [18].

Loading [MathJax]/jax/output/CommonHTML/fonts/TeX/fontdata.js

Page $10 / 27$ 
The present study findings showed no pesticides residues in all the matrices investigated. This can partially be attributed to the degrading nature of pesticides over time as they interact with the environment [30]. In addition, honeybees have the ability to metabolize pesticides in case of exposure through their gut filtering mechanism [31]. Rapid elimination of ingested chemicals by metabolism, advection and deposition has also been reported hence reducing the initial pesticides concentrations [32]. The present study findings are consistent with those of previous studies in the region. Orina [22] reported absence of pesticides residues in all honey samples collected from different sites across 13 regions in Kenya and analyzed for pesticides residues in the laboratory. A pesticide analysis of 171 pesticides on honey samples collected from 13 sites in Kenya by Muli et al., [14] detected only four pesticides; 1naphthol, chlorothalonil, chlorpyrifos and fluvalinate - mostly at very low levels (below $50 \mathrm{ppb}$ ). Similarly, screening of 27 honey samples produced in Switzerland for 36 organochlorine, 32 organophosphorous pesticides and six fungicides returned negative results for pesticides residues. This can be attributed partly to low application rates of pesticides in those countries coupled with strict pesticides regulations in developed countries like Switzerland [27,33]. This shows that it is indeed possible to effectively control agricultural pests with pesticides while maintaining the environmental integrity.

However, the present study findings contrast those from other studies globally that reported residues in honey, pollen and honeybee. For instance, over $90 \%$ of honeybee colonies in the USA reportedly contained over 129 different pesticide-related chemicals, with six chemicals being reported per colony an average $[14,18]$. An analysis of honey samples from Portugal and Spain by Blasco et al., [19] revealed organochlorine pesticides contamination with Portuguese honey samples being more contaminated than Spanish ones. The differences in residues was attributed to the varied volumes consumed and rates of pesticides applied [34]. In addition, Spain puts much more emphasis on pesticide applicator training, which is considered one of the most relevant aspects in the reduction of pesticide exposure thus explaining the differences in honeybee product contamination between Spain and Brazil [30]. Moreover, Kolankaya et al. [35], detected aldrin residues in honey and pollen samples, albeit in very low levels. The same researchers [35] further detected carbosulfan and carboryl pesticides residues in dead honeybees' heads in Ankara, Turkey while Maja et al. [36], reported the presence of fluvalinate honeybee samples after external doses of pesticides were applied to colonies of nine combs, occupied with $20,000-30,000$ adult honeybees in Slovenia. A study of 189 pollen and 226 beebread samples conducted in China established many active pesticide residues, with higher concentrations being noted during spring [37]. Five chemical residues including amitraz and cypermethrin were reported in bee brood samples at concentrations of between 1 and $167 \mu \mathrm{g} / \mathrm{kg}$ in a study conducted in Spain [38].

The low pesticide residue levels in honey compared to the honeybee or its other products can partially be attributed to the filtering effect of bees [31]. Additionally, bees have the capacity to metabolize pesticides immediately there is exposure, further reducing concentrations of remaining pesticide residue [30, 32]. Therefore, the low levels of pesticides in honeybee products from across Kenya, particularly when compared to levels in developed countries points to low pesticide application rates by farmers, hence minimal impact on honeybee health presently in Kenya. 
The survey revealed a declining colony population and production that was attributed to pesticides. Others possible causes were deforestation, drought, pests and predators. Musimba et al. [39] observed a reduction in honey production in arid and semi-arid lands (ASAL) of Kenya in present times compared to the past. Melathopoulos et al., [40], acknowledged the susceptibility of honeybees to pests, diseases and pesticides. In addition, the present study findings reaffirms Claudianos et al. [41] findings that honeybees are susceptible to pesticides due to a deficiency in the number of genes encoding for detoxifying enzymes

The present study findings are consistent with those of Williamson et al., [42] that chemical pest control strategy was the most common among farmers with about 47 different pesticide active ingredients reported by farmers. Further, Macharia et al. [43] found about 62 products, comprising of 36 active ingredients being used for vegetable production in Kenya. This was the case among other vegetable growers in Eastern Africa [44]. Spraying of crop fields with pesticides thus exposes honeybees to hazardous pesticides and is inconsistent with the recommendation that pesticides must be applied to blooming plants and when bees are not foraging - preferably in the early evening [35]. This allows the pesticides time to partially or fully decompose during the night. It is often recommendation that insecticides should be applied only while target plants are in the bud stage or just after the petals have dropped [24].

\section{Limitations}

Albeit this study concentrated on pesticides, other factors may have contributed to the bee rate mortality. Furthermore, as there is no evidence of lost bees in the field due to homing incapability, other methods (such as higher level of detoxification genes in the treated sites or lower LOD analyses) are recommended that would provide a more complete picture. The analysis of beeswax has not been conducted, although pesticides readily accumulate in wax.

\section{Conclusion}

The study established an inverse relationship between pesticides use honeybee mortality rate, with significant increase in mortality rate and reduced honey production being associated with pesticide use. Absence of residues in the matrices in all the studied sites suggests honeybee products from the study setting are still safe for human consumption. Nevertheless, farmers need to be trained on safe handling of pesticides. In addition, there is need for further research on the synergistic impacts of pesticides use on honeybees, and the need for alternative and ecofriendly pest control options to curb the challenge associated with indiscriminate effects of pesticides on other important insects like honeybees.

\section{List Of Abbreviations}

ANOVA - Analysis of Variance 
AOAC - Association of Official Analytical Chemists

CCD - Colony Collapse Disorder

GoK - Government of Kenya

HOAc - Acetic Acid

KALRO - Kenya Agricultural and Livestock Research Organization

Kg - Kilogram

KNBS - Kenya National Bureau of Statistics

KTBH - Kenya Top Bar Hive

LC-MS/MS- Tandem Liquid Chromatography/Mass Spectrometry/Mass Spectrometry

LD50 - Median Lethal Dose

LOD - Limit of Detection

LOQ - Limit of Quantification

MeCN - Acetonitrile

MgSO4 - Magnesium Sulfate mL - millilitre

$\mathrm{MPH}$ - Metres Per Hour

MRL - Maximum Residue Limit

$\mathrm{NaOAc}$ - Sodium Acetate NBS - National Beekeeping Station

PAN - Pesticide Action Network

PCPB - Pest Control Products Board

PSA - Primary Secondary Amine

SGS - Societe General De Surveillance

SPE - Solid-Phase Extraction SPSS - Statistical Package for Social Scientists

\section{Declarations}


Ethical approval to carry out this study was obtained from Maseno University Ethical Review Committee.

Participation in this study was voluntary for all participants and each of them gave their written informed consent to participate in the study. Participants' confidentiality was assured by ensuring that any data identifying individuals was coded and not shared to any third party.

\section{Consent for Publication}

None required

\section{Competing interests}

The authors declare that there is no conflict of interest.

\section{Consent for Publication}

Not Applicable

\section{Availability of data and materials}

All data generated or analysed during this study are included in this published article

\section{Competing Interest}

The authors declare no conflict of interest.

\section{Funding}

Not applicable

\section{Author contributions}

$\mathrm{KR}, \mathrm{GD}, \mathrm{PA}$ and DA conceived the idea, collected the data, conducted the statistical analyses, and drafted the manuscript. TM and MO helped in critically evaluating the manuscript and provided feedback on the planning, study design and methodology. All authors read and edited the manuscript and provided useful critique. All authors approved the final version of this article.

\section{Acknowledgements}

We would like to thank the former Director KARI; Dr. Ephraim Mukhisira, the AD; human resource development; Mr. Martin Kivui for authorizing my part time studies. In addition, we would like to thank the Pro-poor project team members. Honest appreciation are extended to Mr. Nelson Kidula, KALRO Kisii Biometrician for his invaluable contribution in data analysis and interpretation, as well as Mr. Stanley Bett for his technical and field logistical support without which this study would not have been a success. 
1. Degrandi-Hoffman, G., Henry, G., Fabiana, A., Matthew S., Nick, Z. (2019). The economics of honeybee (hymenoptera: Apidae) management and overwintering strategies for colonies used to pollinate almonds. Journal of economic entomology, 112(6):2524- 2533.

2. VanEngelsdorp D. and Meixner M.D. (2010). A historical review of managed honeybee populations in Europe and the United States and the factors that may affect them. Journal of Invertebrate Pathology, 103: S80-S95.

3. Getachew A.(2018). Assessment on the Constraints \& Practices of Beekeeping, and Post-Harvest Honey Handling in Gesha District,Keffa Zone, South-West Ethiopia. Agri Res \& Tech: Open Access J; 16(1): 555974. DOI: 10.19080/ARTOAJ.2018.16.555974

4. Alaux C., Brunet L., Dussaubat C., Mondet F., Tchamitchan S., Cousin M., Brillard J., Baldy A., Belzunces P., Le Conte Y. (2010). Interactions between Nosema microspores and a neonicotinoid weaken honeybees (Apis mellifera). Environmental Microbiology, 12: 774-782.

5. Gray, A., Brodschneider, R., Adjlane, N., Ballis, A., Brusbardis, V., Charrière, J.-D., Chlebo, R., Coffey, M., F., Cornelissen, B., Amaro da Costa, C., Csáki, T., Dahle, B., Danihlík, J., Dražić, M.M., Evans, G., Fedoriak, M., Forsythe, I., de Graaf, D., Gregorc, A., Johannesen, J., Kauko, L., Kristiansen, P., Martikkala, M., Martín-Hernández, R., Medina-Flores, C.A., Mutinelli, F., Patalano, S., Petrov, P., Raudmets, A., Ryzhikov, V.A., Simon-Delso, N., Stevanovic, J., Topolska, G., Uzunov, A., Vejsnaes, F., Williams, A., Zammit-Mangion, M., Soroker, V. (2019). Loss rates of honey bee colonies during winter $2017 / 18$ in 36 countries participating in the COLOSS survey, including effects of forage sources. J. Apic. Res. 58, 479-485.

6. Vidau C., Diogon M., Aufauvre J., Fontbonne R., Vigues B., Brunet J. L., Texier C., Biron D. G., Blot N., Alaoui H. E., Belzunces L. P., Delbac F. (2011). Exposure to sublethal doses of fipronil and thiacloprid highly increases mortality of honeybees previously infected by Nosema ceranae. PLOS ONE 6, e21550. doi:10.1371/journal.pone.0021550 Medline.

7. Bommuraj, V., Chen, Y., Birenboim, M., Barel, S. \& Shimshoni, J.A. (2020). Concentration- and timedependent toxicity of commonly encountered pesticides and pesticide mixtures to honeybees (Apis mellifera L.) Chemosphere 128974, doi: 10.1016/j.chemosphere.2020.128974. Online ahead of print.

8. PAN Factsheet (2012). Sub-lethal and chronic effects of neonicotinoids on bees and other pollinators. Bee declines \& pesticides. Factsheet 2: 1-8.

9. Whitehorn, P. R., O’Connor, S., Wackers, F. L. \& Goulson, D. (2012). Neonicotinoid pesticide reduces bumblebee colony growth and queen production. Science 336, 351-352.

10. Henry M. and Beguin M. (2012). A common pesticide decreases foraging success and survival in honeybees. Science, 336, 348-350.

11. Munyuli, M. B. T. (2014). Is cut-flower industry promotion by the government negatively affecting pollinator biodiversity and environmental/human health in Uganda? ISRN Biodivers., 2014, 368953

12. Kajobe R., Godfrey J., Kugonza R., Alioni V., Otim A. and Rureba T. (2009). National beekeeping calendar, honeybee pest and disease control methods for improved production of honey and other 
13. KNBS (2007). Kenya national adult literacy survey report, 2007.

14. KNBS. (2010). Kenya National Bureau of Statistics. Retrieved November 25, 2014, from http//www.knbs.or.ke/Census Results

15. Muli, E., Patch, H., Frazier, M., Frazier, J., Torto, B., et al. (2014). Evaluation of the distribution and impacts of parasites, pathogens, and pesticides on honeybee (Apis mellifera) populations in East Africa. PLoS One 9.

16. Carroll, T. (2002). A study of the beekeeping sector in Kenya, pp. 11-12

17. Mutungi, E.M (1998). Factors affecting honey production in southeast Kenya Rangelands: a case study of Kibwezi Division, Makueni District. Thesis Report, University of Nairobi, 1998.

18. GoK (2015). Transmara district strategic plan 2005 - 2010 for implementation of the national population policy for sustainable development.

19. Fikadu, Z. (2020). Pesticides use, practice and its effect on honeybee in Ethiopia: a review. J. Trop. Insect Sci. https:// doi.org/10.1007/s42690-020-00114-x

20. Warui, M. W., L. Hansted, M. Gikungu, J. Mburu, G. Kironchi \& A. S. Bosselmann (2019). Characterization of Kenyan honeys based on their physicochemical properties, botanical and geographical origin. International Journal of Food Science, 2019, 2932509.

21. McMenamin, A.; Mumoki, F.; Frazier, M.; Kilonzo, J.; Mweu, B.; Baumgarten, T.; Patch, H.; Torto, B.; Masiga, D.; Tumlinson, J.; et al. The impact of hive type on the behavior and health of honeybee colonies (Apis mellifera) in Kenya. Apidologie 2017.

22. Mugo, B., Syomiti, M., Hoag, D. \& Gebru, G. (2015). "The status of improved beekeeping technologies as resource diversification for addressing climate change risks in Kajiado County, Kenya: constraints and opportunities. Livestock Research for Rural Development 27 (8).

23. Teeters B.S., Johnson R.M., Ellis M.D., Siegfried B.D. (2012). Using video-tracking to assess sublethal effects of pesticides on honeybees (Apis mellifera L.). Environ Toxicol Chem 31: 1349-1354.

24. Sanford, T.M. (2011). Protecting honeybees from pesticides. Circular 534, Florida Cooperative Extension Service, Institute of Food and Agricultural Sciences, University of Florida.

25. Desneux N., Decourtye A. and Delpuech J.M. (2007). The sub lethal effects of pesticides on beneficial arthropods. Annu. Rev. Entomol. 52: 81-106.

26. Mommaerts, V, Reynders, S, Boulet, J, Besard, L, Sterk, G and Smagghe, G. (2010) Risk Assessment for Side-effects of Neonicotinoids against Bumblebees with and without Impairing Foraging Behavior. Ecotoxicology 19 (1): 207-215.

27. Colin M.E., Bonmatin J.M., Moineau I., Gaimon C., Brun S., Vermandere J.P. (2004). A method to quantify and analyze the foraging activity of honeybees: relevance to the sublethal effects induced by systemic insecticides. Arch Environ Contam Toxicol, 47:387-395.

28. Vandame, R., Meled, M., Colin, M. E., and Belzunces, L. P. (1995). Alteration of the homingflight in the honeybee Apis mellifera $L$ exposed to sublethal dose of deltamethrin. Environmental Toxicology and Chemistry 14: 855-860.

Loading [MathJax]/jax/output/CommonHTML/fonts/TeX/fontdata.js

Page $16 / 27$ 
29. Vandame, R., Meled, M., Colin, M. E., and Belzunces, L. P. (1995). Alteration of the homingflight in the honeybee Apis mellifera $L$ exposed to sublethal dose of deltamethrin. Environmental Toxicology and Chemistry 14: 855-860.

30. Mullin C.A., Frazier M., Frazier J.L., Ashcraft S., Simonds R., vanEngelsdorp D., Pettis J.S. (2010). High levels of miticides and agrochemicals in North American apiaries: Implications for honeybee health. PLoS ONE 5, e9754.

31. Schur A. and Wallner K. (2000). Assessment of the individual active ingredient entry by collecting bees after Pesticides application in thriving cultures, Apidologie31, 615-616

32. Tremolada P., Bernardinelli I., Colombo M., Spreafico M. Vighi M. (2004). Coumaphos distribution in the hive ecosystem: Case study for modeling applications, Ecotoxicology 13: 589-601.

33. WenJun Z., FuBin J. and JianFeng O., (2011). Global pesticide consumption and pollution: with China as a focus. Proceedings of the international academy of ecology and environmental Sciences, 1(2):125-144.

34. Reus J. and Leendertse P. (2000). The environmental yardstick for pesticides: A practical indicator used in the Netherlands. Crop Protection 19: 637-641.

35. Kolankaya D., Erkmen B., Sorkun K., and Kocak O. (2002). Pesticide Residues in honeybees and some honeybee products in Turkey. Scientific paper Naucni rad UDK: 638.15021-099 (560).

36. Maja I., Smodis S., Kmecl V., and Gregorc A. (2010). Exposure to Pesticides at Sublethal Level and Their Distribution within a Honey Bee (Apis mellifera) Colony. Bull Environ Contam Toxicol, 85:125128.

37. Tong, Z., Duan, J., Wu, Y., Liu, Q., He, Q., Shi, Y., Yu, L. \& Cao, H. (2018). A survey of multiple pesticide residues in pollen and beebread collected in China. Science of the Total Environment 640-641: 15781586. doi: 10.1016/j.scitotenv.2018.04.424.

38. Murcia, M., M., Gómez, R., M., J., Parrilla, V., P., Díaz, G., F.J., García, V., M., Gámiz, L., V., Manuel, F., J., Fernández-Alba, A.R. (2020). Distribution of chemical residues in the beehive compartments and their transfer to the honeybee brood. Science of the Total Environment 710: 136288. doi:

10.1016/j.scitotenv.2019.136288.

39. Musimba N., Nyariki D. and Mutungi E. (2001). The socioeconomics, culture and ecology of beekeeping among the Akamba community of Southern Kenya. J.Hum. Ecol., 12(3): $207-216$

40. Melathopoulos, A., Winston M., Whittington R., Smith T., Lindberg C., Mukai A. and Moore M. (2000). Comparative laboratory toxicity of neem pesticides to honey bees (Hymenoptera: Apidae), their mite parasites Varroa jacobsoni (Acari:Varroidae) and Acarapis woodi (Acari: Tarsonemidae), and brood pathogens Paeni bacillus larvae and Ascophaeraapis. J. Econ. Entomol. 93:199-209.

41. Claudianos C., Ranson H., Johnson R.M., Biswas S., Schuler M.A., Berenbaum M.R., Feyereisen R., Oakeshott J.G. (2006). A deficit of detoxification enzymes: pesticide sensitivity and environmental response in the honeybee. Insect Mol. Biol. 15, 615-636.

42. Williamson S., Ball A., Pretty J. (2008). Trends in pesticide use and drivers for safer pest 
43. Macharia I., Mithofer D. and Waibel H. (2009). Potential environmental impacts of pesticides use in the vegetable sub-sector in Kenya. Afr. J. Hort. Sci. 2: 138-151.

44. Sithanantham S. (2004). Development and dissemination of IPM for vegetables in Eastern Africa. Icipe science Press.

\section{Tables}

Table 1. Honeybee mortality rate on selected colonies in Transmara West Sub-County

\begin{tabular}{|llll|}
\hline Treatments & \multicolumn{3}{l}{ Mortality rate (Mean dead bees per station per week) \pm SE } \\
\cline { 2 - 4 } & Season 1 & Season 2 & Mean \\
\hline On-farm & $68.0 \pm 6.1^{\mathrm{b}}$ & $85 \pm 5.3^{\mathrm{b}}$ & $77 \pm 5.9^{\mathrm{b}}$ \\
\hline Control & $64.0 \pm 10^{\mathrm{b}}$ & $82 \pm 13^{\mathrm{b}}$ & $73 \pm 12.0^{\mathrm{b}}$ \\
\hline Treatment1 & $229 \pm 6.2^{\mathrm{a}}$ & $228 \pm 3.5^{\mathrm{a}}$ & $229 \pm 4.9^{\mathrm{a}}$ \\
\hline Treatment2 & $231 \pm 5.1^{\mathrm{a}}$ & $230 \pm 4.2^{\mathrm{a}}$ & $231 \pm 4.7^{\mathrm{a}}$ \\
\hline Treatment3 & $235 \pm 4.3^{\mathrm{a}}$ & $232 \pm 3.8^{\mathrm{a}}$ & $234 \pm 4.1^{\mathrm{a}}$ \\
\hline MSD & 5.9655 & 3.3919 & 4.6791 \\
\hline Mean & 165 & 171 & \\
\hline
\end{tabular}

$n=60$ colonies; Means with the same superscripts within the column are not significantly different (Tukey test). Treatments: 1= Magic and keshet, 2=Almatix, sypertix and steladone, 3= Magic, keshet, almatix, sypertix and steladone.

Table 2. Honey yields on selected colonies in Transmara West Sub-County 


\begin{tabular}{|llll|}
\hline Treatments & \multicolumn{3}{l}{ Honey yields (Mean \pm SE) kg } \\
\cline { 2 - 4 } & Season 1 & Season 2 & Mean \\
\hline Control & $18.0 \pm 1.00^{\mathrm{a}}$ & $22.50 \pm 1.50^{\mathrm{a}}$ & $20.30 \pm 1.3^{\mathrm{a}}$ \\
\hline On-farm & $12.20 \pm 1.80^{\mathrm{b}}$ & $16.23 \pm 2.05^{\mathrm{b}}$ & $14.22 \pm 1.93^{\mathrm{b}}$ \\
\hline Treatment1 & $7.1 \pm 1.80^{\mathrm{b}}$ & $11.00 \pm 1.20^{\mathrm{b}}$ & $9.0 \pm 1.2^{\mathrm{b}}$ \\
Treatment2 & $8.4 \pm 1.50^{\mathrm{b}}$ & $15.0 \pm 1.40^{\mathrm{b}}$ & $11.7 \pm 1.5^{\mathrm{b}}$ \\
\hline Treatment3 & $9.2 \pm 1.70^{\mathrm{b}}$ & $13.0 \pm 1.30^{\mathrm{b}}$ & $11.0 \pm 1.6^{\mathrm{b}}$ \\
\hline MSD & 5.3431 & 4.3415 & 4.8425 \\
\hline Mean & 10.98 & 15.55 & \\
\hline
\end{tabular}

$\mathrm{n}=60$ colonies; MSD = Mean Standard Deviation: Means with the same superscripts within the column are not significantly different (Tukey test) Means with the same superscript within the column are not significantly different, at $p=0.05$ (Tukey test). Treatments: $1=$ Magic and keshet, $2=$ Almatix, sypertix and steladone, 3 = Magic, keshet, almatix, sypertix and steladone.

Table 3. Analytical results of honey, pollen and honeybee samples in Transmara West Sub-County 


\begin{tabular}{|c|c|c|c|c|c|c|}
\hline Matrix & $\begin{array}{l}\text { Pesticide } \\
\text { trade } \\
\text { name }\end{array}$ & $\begin{array}{l}\text { Active } \\
\text { ingredient (A.I) }\end{array}$ & $\begin{array}{l}\text { Pesticides } \\
\text { levels in } \\
\text { sample } \\
(\mathrm{mg} / \mathrm{Kg})\end{array}$ & $\begin{array}{l}\text { Limit of } \\
\text { detection } \\
(\mathrm{mg} / \mathrm{Kg})\end{array}$ & $\begin{array}{l}\text { Limit of } \\
\text { quantification } \\
\text { (mg } / \mathrm{Kg} \text { ) }\end{array}$ & $\begin{array}{l}\text { Mean } \pm \\
\text { SE of } \\
\text { recoveries }\end{array}$ \\
\hline \multirow[t]{5}{*}{ Honey } & Almatix & Amitraz & $<$ LOD & 0.01 & 0.01 & $90 \pm 3.0$ \\
\hline & Magic & Malathion & $<$ LOD & 0.01 & 0.05 & $87 \pm 5.7$ \\
\hline & Steladone & Chlorfenvinphos & $<$ LOD & 0.01 & 0.05 & $94 \pm 3.7$ \\
\hline & Sypertix & Cypermethrin & $<$ LOD & 0.01 & 0.01 & $92 \pm 4.3$ \\
\hline & Keshet & Deltamethrin & $<$ LOD & 0.01 & 0.01 & $93 \pm 1.5$ \\
\hline \multirow[t]{5}{*}{ Pollen } & Almatix & Amitraz & $<$ LOD & 0.01 & 0.01 & $90 \pm 3.0$ \\
\hline & Magic & Malathion & $<$ LOD & 0.01 & 0.05 & $87 \pm 5.7$ \\
\hline & Steladone & Chlorfenvinphos & $<$ LOD & 0.01 & 0.05 & $94 \pm 3.7$ \\
\hline & Sypertix & Cypermethrin & $<$ LOD & 0.01 & 0.01 & $92 \pm 4.3$ \\
\hline & Keshet & Deltamethrin & $<$ LOD & 0.01 & 0.01 & $93 \pm 1.5$ \\
\hline \multirow[t]{5}{*}{ Honeybee } & Almatix & Amitraz & $<$ LOD & 0.01 & 0.01 & $90 \pm 3.0$ \\
\hline & Magic & Malathion & $<$ LOD & 0.01 & 0.05 & $87 \pm 5.7$ \\
\hline & Steladone & Chlorfenvinphos & $<$ LOD & 0.01 & 0.05 & $94 \pm 3.7$ \\
\hline & Sypertix & Cypermethrin & $<$ LOD & 0.01 & 0.01 & $92 \pm 4.3$ \\
\hline & Keshet & Deltamethrin & $<$ LOD & 0.01 & 0.01 & $93 \pm 1.5$ \\
\hline
\end{tabular}

$n=80$ matrices; $<$ LOD $=$ below limit of detection

Table 4: Demographic factors of farmers in Transmara West Sub-County 


\begin{tabular}{|lllllll|}
\hline Age & Angata $\mathrm{n}(\%)$ & P-value & Kilgoris $\mathrm{n}(\%)$ & P-value & Lolgorian & P-value \\
\hline 18-35 years & $27(29.0)$ & 0.071 & $82(49.1)$ & $<0.001$ & $34(48.6)$ & 0.003 \\
\hline $36-50$ years & $41(44.1)$ & & $67(40.1)$ & & $21(30.0)$ & \\
\hline$>50$ years & $25(26.9)$ & & $18(10.8)$ & & $15(21.4)$ & \\
\hline Level of education & & & & & & \\
\hline Primary/informal & $67(72.0)$ & $<0.001$ & $133(79.6)$ & $<0.001$ & $51(72.9)$ & $<0.001$ \\
\hline Secondary & $20(21.5)$ & & $24(14.4)$ & & $17(24.3)$ & \\
\hline University/College & $6(6.5)$ & & $10(6.0)$ & & $2(2.9)$ & \\
\hline
\end{tabular}

Table 5. Pesticides used by livestock and crop farmers in Transmara West Sub-County 


\begin{tabular}{|c|c|c|c|c|c|}
\hline $\begin{array}{l}\text { Pesticide chemical } \\
\text { group }\end{array}$ & $\begin{array}{l}\text { Pesticide } \\
\text { Trade name }\end{array}$ & $\begin{array}{l}\text { Active } \\
\text { ingredient (A.I) }\end{array}$ & $\begin{array}{l}\text { WHO } \\
\text { toxicity } \\
\text { class }\end{array}$ & $\begin{array}{l}\text { Registration } \\
\text { status } \\
\text { (PCPB) }\end{array}$ & $\begin{array}{l}\text { Farmers } \\
\text { using } \\
\text { (\%) }\end{array}$ \\
\hline \multirow[t]{5}{*}{ Formamidine } & Almatix & Amitraz & II & Registered & $\begin{array}{l}26 \\
(37.1)\end{array}$ \\
\hline & Bye bye & Amitraz & II & Registered & $3(4.3)$ \\
\hline & Norotraz & Amitraz & II & Registered & $\begin{array}{l}13 \\
(18.6)\end{array}$ \\
\hline & Tixfix & Amitraz & II & Registered & $\begin{array}{l}10 \\
(14.3)\end{array}$ \\
\hline & Triatix & Amitraz & II & Registered & $\begin{array}{l}18 \\
(25.7)\end{array}$ \\
\hline \multirow[t]{5}{*}{ Organophosphorous } & Diazol & Diazinon & II & Registered & $\begin{array}{l}19 \\
(20.4)\end{array}$ \\
\hline & Neocidol & Diazinon & II & Registered & $\begin{array}{l}16 \\
(17.2)\end{array}$ \\
\hline & Magic & Malathion & II & Registered & $\begin{array}{l}28 \\
(30.1)\end{array}$ \\
\hline & Oshothion & Malathion & II & Registered & $\begin{array}{l}22 \\
(23.7)\end{array}$ \\
\hline & Steladone & Chlorfenvinphos & $\mathrm{lb}$ & Registered & $8(8.6)$ \\
\hline \multirow[t]{10}{*}{ Pyrethroids } & Alfapor & Cypermethrin & II & Registered & $8(4.8)$ \\
\hline & Alphacymba & Cypermethrin & II & Registered & $\begin{array}{l}23 \\
(13.8)\end{array}$ \\
\hline & Dominex & Cypermethrin & $\|$ & Registered & $\begin{array}{l}18 \\
(10.8)\end{array}$ \\
\hline & Sypertix & Cypermethrin & II & Registered & $\begin{array}{l}38 \\
(22.8)\end{array}$ \\
\hline & Cybadip & Cypermethrin & $\|$ & $\begin{array}{l}\text { Not } \\
\text { Registered }\end{array}$ & $15(9.0)$ \\
\hline & Ectomin & Cypermethrin & II & Registered & $9(5.4)$ \\
\hline & Grenade & Cyhalothrin & II & Registered & $15(9.0)$ \\
\hline & Delete & Deltamethrin & II & Registered & $9(5.4)$ \\
\hline & Keshet & Deltamethrin & $\|$ & Registered & $\begin{array}{l}26 \\
(15.6)\end{array}$ \\
\hline & Vectocid & Deltamethrin & ॥ & Registered & $6(3.6)$ \\
\hline
\end{tabular}


$\mathrm{n}=330$, Toxicity classes: la = Extremely harzardous, lb = Highly harzardous, II = moderately harzardous, III = slightly harzardous $(\mathrm{WHO}, 2010)$.

Table 6. Colony strength dynamics in Transmara West Sub-County

\begin{tabular}{|c|c|c|c|c|c|c|}
\hline $\begin{array}{l}\text { Initial colony } \\
\text { strength }\end{array}$ & $\begin{array}{l}\text { Angata } \\
\mathrm{n}(\%)\end{array}$ & $\begin{array}{l}\mathrm{P}- \\
\text { value }\end{array}$ & $\begin{array}{l}\text { Kilgoris } \\
\mathrm{n}(\%)\end{array}$ & $\begin{array}{l}\mathrm{P} \text { - } \\
\text { value }\end{array}$ & $\begin{array}{l}\text { Lolgorian } \\
\text { n(\%) }\end{array}$ & $\begin{array}{l}\mathrm{P}- \\
\text { value }\end{array}$ \\
\hline Big and strong & $54(58.1)$ & $<0.001$ & $98(58.7)$ & $<0.001$ & $34(48.6)$ & $<0.001$ \\
\hline Small and weak & $6(6.5)$ & & $5(3.0)$ & & $1(1.4)$ & \\
\hline High honey yielder & 31 (33.3) & & $60(36.0)$ & & $34(48.6)$ & \\
\hline Low honey yielder & $2(2.2)$ & & $4(2.4)$ & & $1(1.4)$ & \\
\hline \multicolumn{7}{|l|}{ Color change } \\
\hline Yes & $60(64.5)$ & $<0.001$ & $102(61.1)$ & 0.027 & $55(64.3)$ & $<0.001$ \\
\hline No & $33(35.5)$ & & $65(39.0)$ & & $15(21.4)$ & \\
\hline \multicolumn{7}{|l|}{ Observed changes } \\
\hline Reduced size & $43(46.2)$ & $<0.001$ & $29(17.4)$ & $<0.001$ & $42(60.0)$ & $<0.001$ \\
\hline Weakened colony & $11(11.8)$ & & $50(30.0)$ & & $4(5.7)$ & \\
\hline Lower honey yield & 39 (41.9) & & 88 (52.2) & & $24(34.3)$ & \\
\hline \multicolumn{7}{|l|}{ Causes of decline } \\
\hline Pesticides & $64(68.8)$ & $<0.001$ & $66(39.5)$ & 0.001 & $35(50.0)$ & $<0.001$ \\
\hline Deforestation & $20(21.5)$ & & $50(30.0)$ & & $19(27.1)$ & \\
\hline Drought/storm & $5(5.4)$ & & $30(18.0)$ & & $14(20.0)$ & \\
\hline Pests and predators & $4(4.3)$ & & $21(12.6)$ & & $2(2.9)$ & \\
\hline
\end{tabular}

\section{Figures}




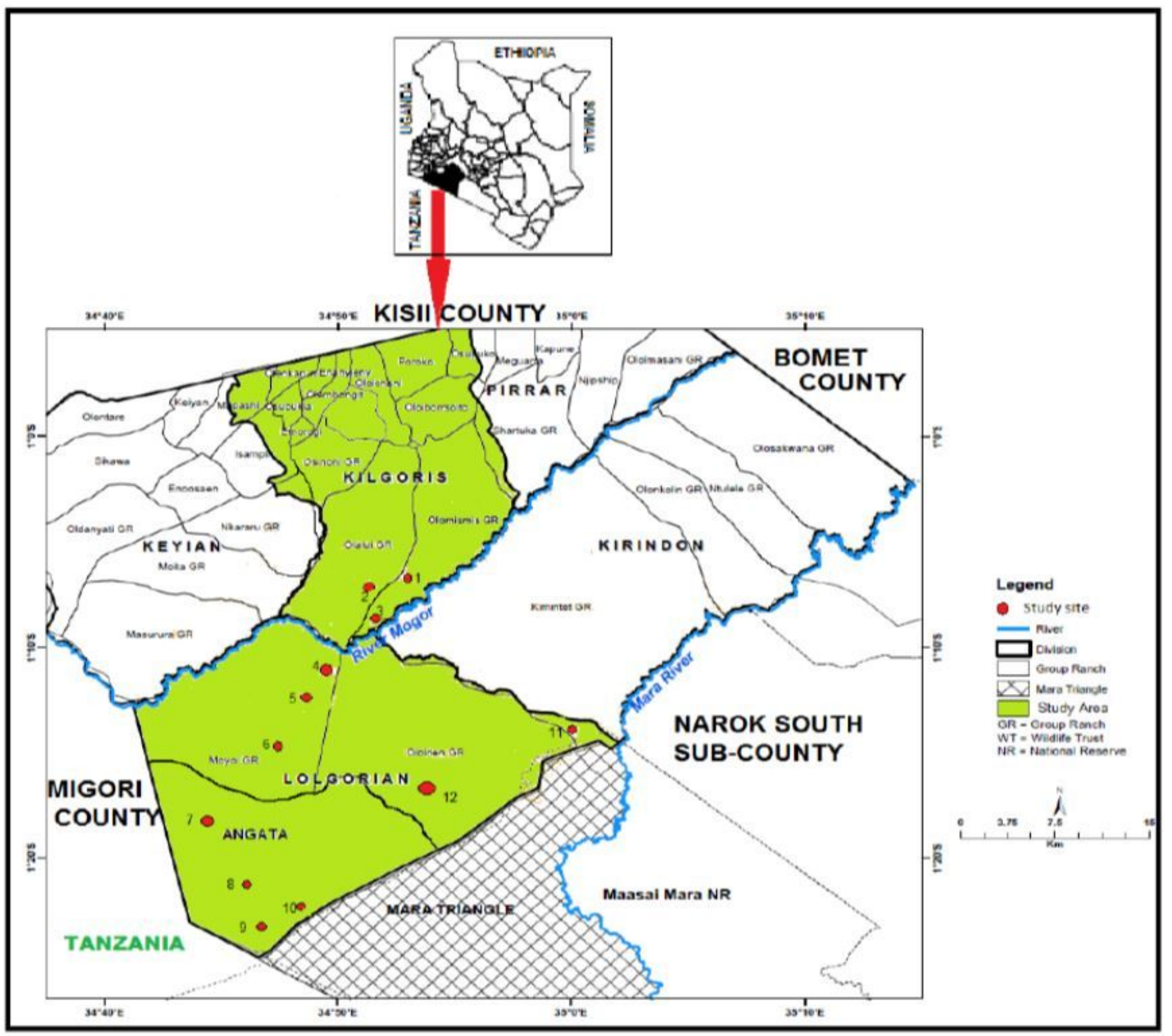

Figure 1

Kenya map showing Trans Mara West sub-county and the study sites [18] Note: The designations employed and the presentation of the material on this map do not imply the expression of any opinion whatsoever on the part of Research Square concerning the legal status of any country, territory, city or area or of its authorities, or concerning the delimitation of its frontiers or boundaries. This map has been provided by the authors. 


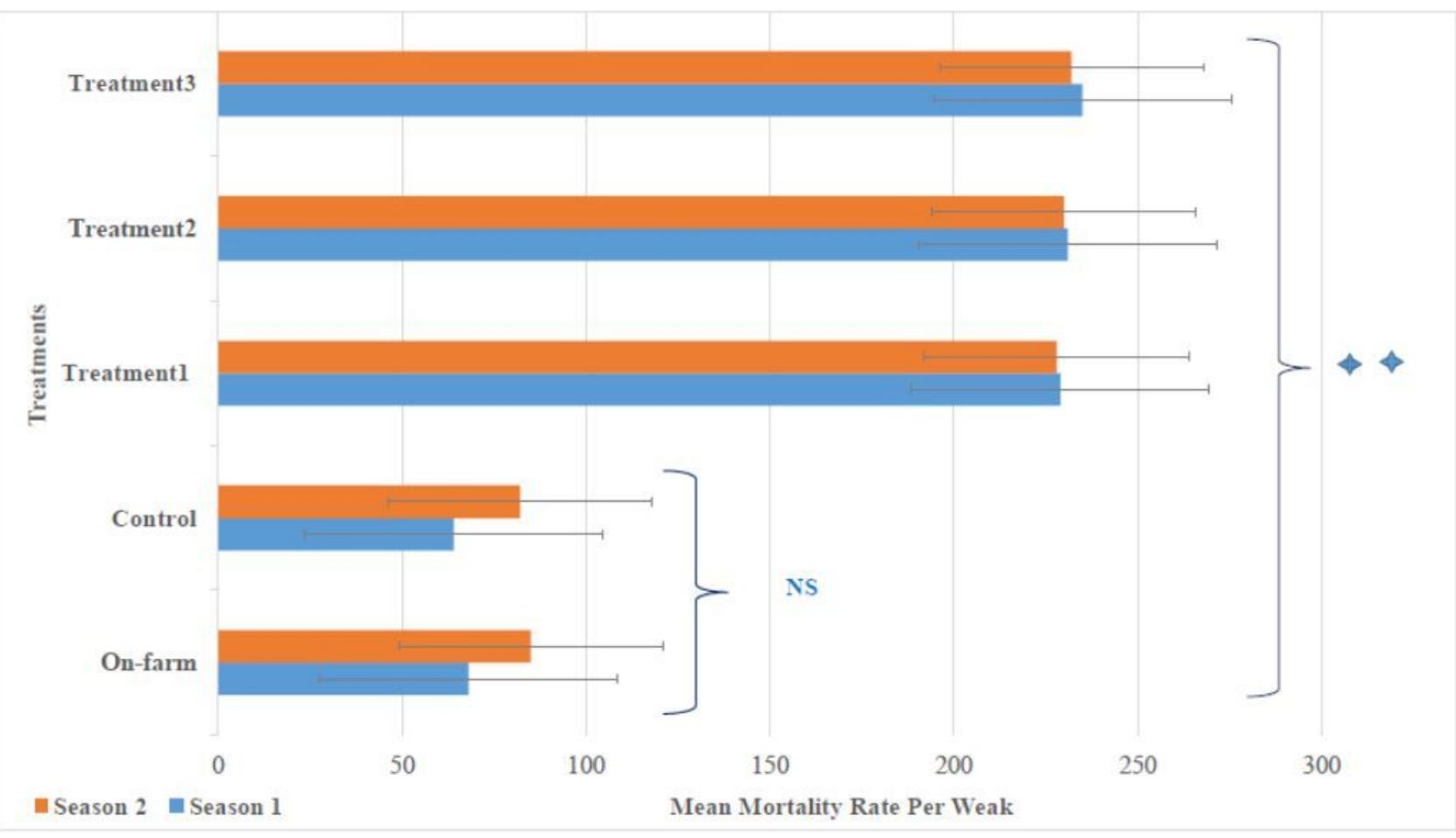

\section{Figure 2}

Observed differences in in Honeybee mortality rates in Transmara West Sub-County

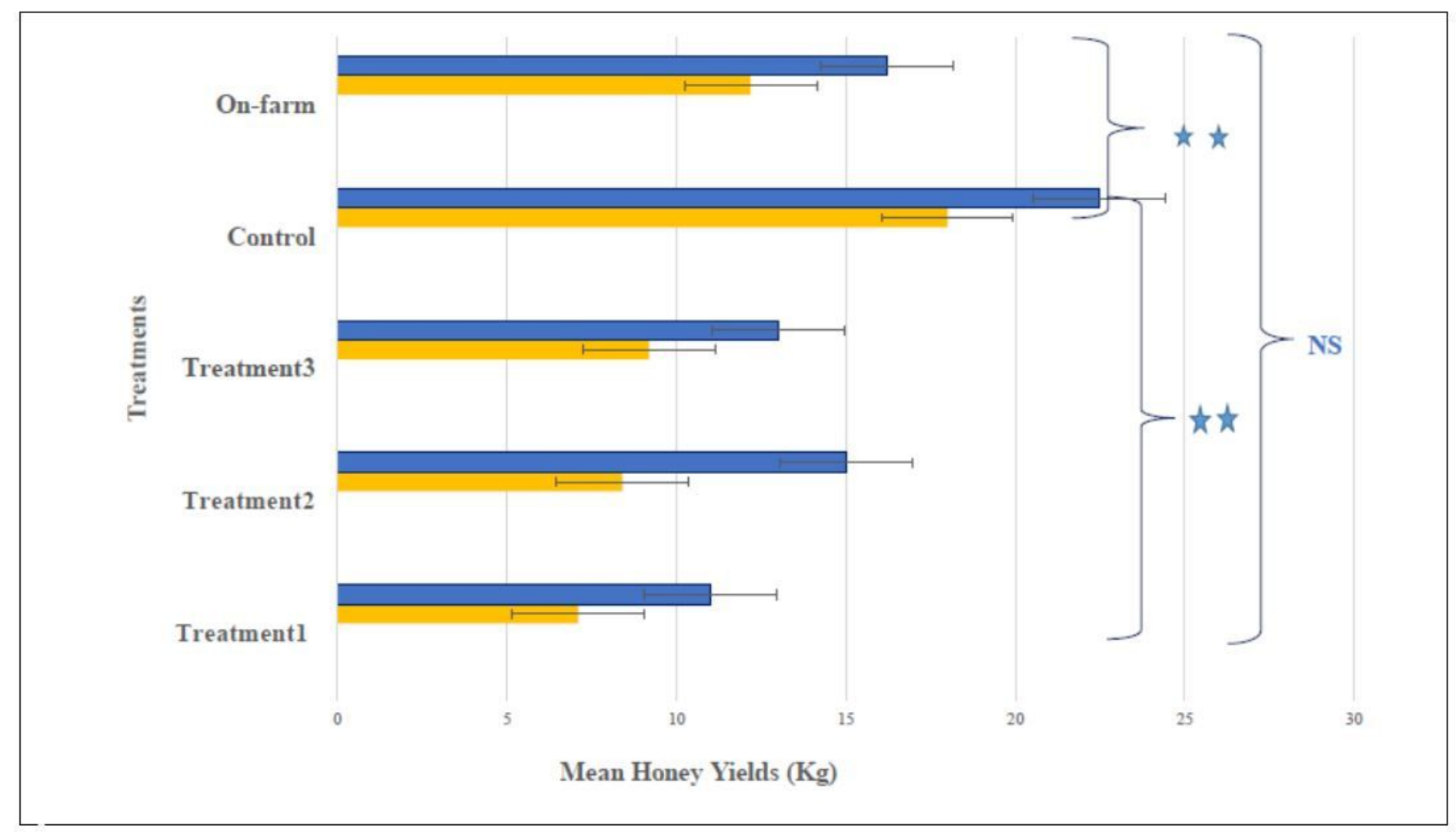




\section{Figure 3}

Observed differences in honey yields on selected colonies in Transmara West Sub-County

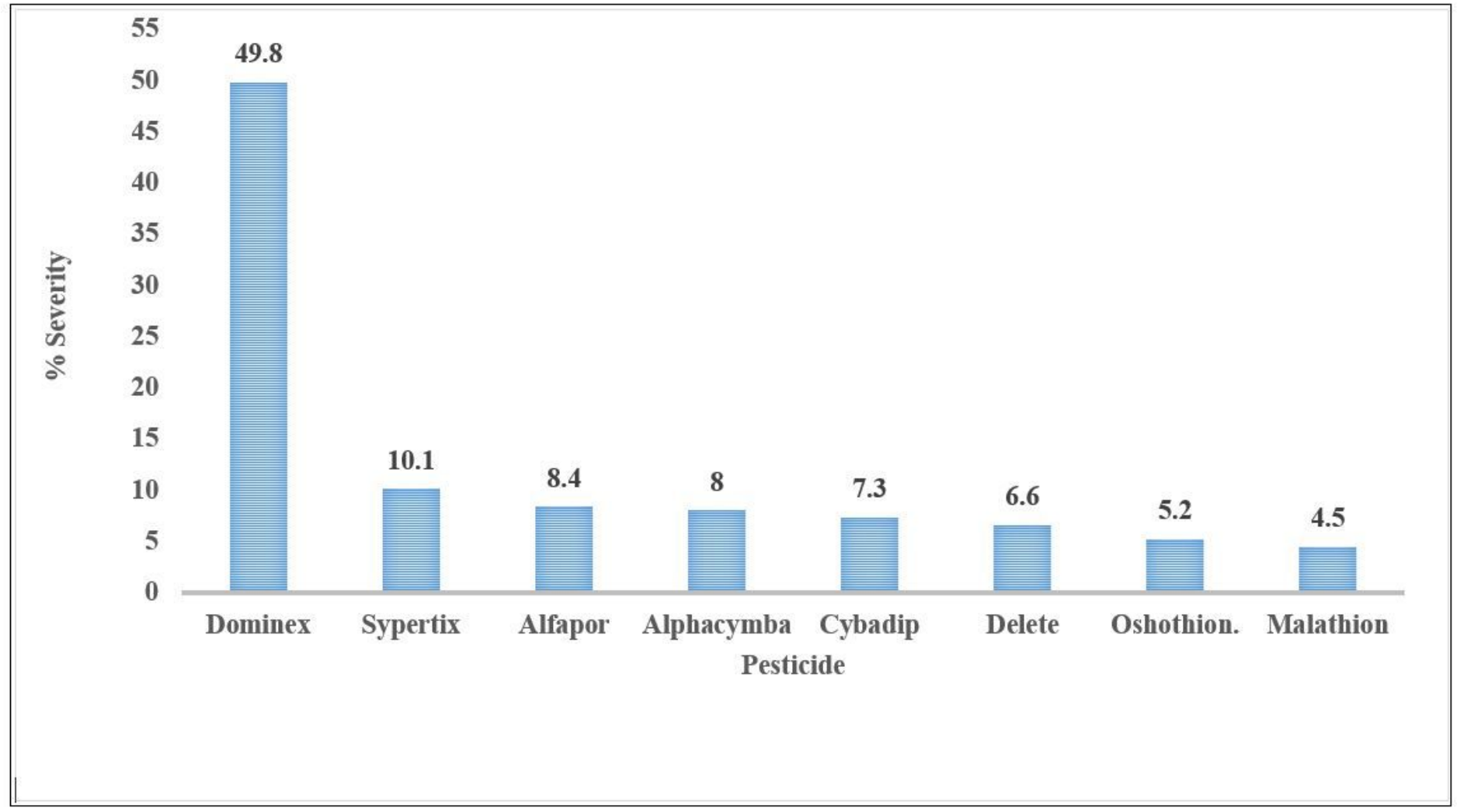

Figure 4

Severity of pesticides to honeybees in Transmara West Sub-County 


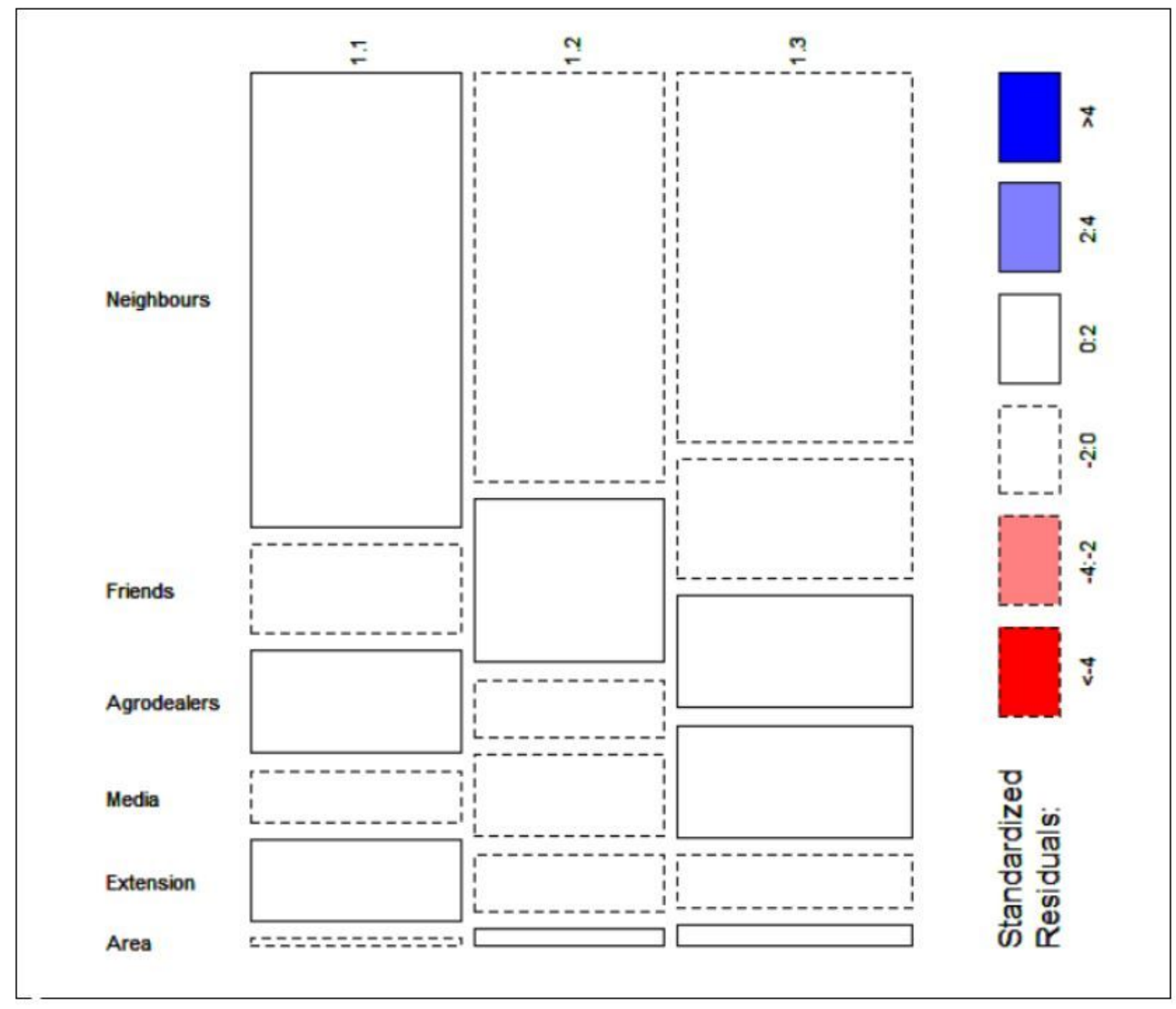

Figure 5

Major information sources on pesticide use by farmers in Transmara West Sub-County

\section{Supplementary Files}

This is a list of supplementary files associated with this preprint. Click to download.

- Slide1.docx

- Slide2.docx 